\title{
A SIMULATED STUDY OF IMPACT OF ENVIRONMENTAL FACTORS ON INDOOR WORKER PERFORMANCE
}

\author{
A.H.EL-abd ${ }^{1}$, W.M.Shewakh ${ }^{1,2}$ \\ 1 Industrial Engineering Department, Faculty of Engineering, Jazan University, Saudi Arabia \\ E-mail:dralielabd@yahoo.com \\ 2 Production Technology Department, IE College, Beni-Suef University, Egypt \\ E-mail:waleedshewakh@hotmail.com
}

\begin{abstract}
The objective of the study is to explore worker effectiveness with changes in noise and temperature indoors. The experiment is carried out in the south-western part of the Kingdom of Saudi Arabia. Thirty-three Saudi young male subjects were used as sample. Three groups of 11 participants in each group were exposed to controlled environmental conditions of four different temperatures and three noise levels, and time of completion of task recorded to perform an assembly. It is found that the optimal temperature and noise level for the simulated study on the subjects is $18^{\circ} \mathrm{C}$ and $45 \mathrm{dBA}$ respectively. The results indicate that the performance of an indoor worker in Saudi Arabia is affected by the change of temperature and noise level.
\end{abstract}

Keywords: Temperature, Noise, Efficiency of worker, Indoor workers.

\section{INTRODUCTION}

Early researches mainly focused on factory or largely manual work. With the changing nature of work, office work performance contributes substantially to productivity gain in today's world [1], and recent research has focused on the impact of indoor environment quality on office work $[2,3]$. Research results show that the indoor environment of office workers has a direct influence on productivity vis-à-vis job stress and job satisfaction $[4,5]$. Therefore improving indoor environment is deemed to be the most important factor in office productivity study in order to enhance satisfaction. The indoor environment quality covers several factors, including thermal environment, indoor air quality, lighting, and acoustic $[6,7]$. Existing literature suggests a complex relationship between high temperature and mental work performance. Niemela et al. [8] reported a decrement in productivity of call center workers when the temperature was above $25^{\circ} \mathrm{C}$. Pepler and Warner [9] found an inverse U-shape relationship between time to complete a task and temperature, with the longest time to complete assignment work at $26.7^{\circ} \mathrm{C}$. The general effect of industrial noise on the annoyance of workers has led to regulations limiting noise exposures of industrial workers, e.g. in USA, Occupational Noise Exposure Regulation (ONER) states that industrial employers must limit noise exposure of their employees to $90 \mathrm{dBA}$ for an 8-h period [10]. While Saudi Arabia's economic base continues to be dominated by oil, the Kingdom has taken steps to diversify the economy. Today, industrial products make up more than 90 percent of the Kingdom's non- 
oil exports [11]. Hence, because of rapid development in Kingdom of Saudi Arabia, more and more workers are involved in indoor activities and it becomes imperative to determine optimal environmental conditions for their efficient performance and to explore the effect of temperature and noise on their efficiency. Very little work has been done in this area in the whole of the country, while no research has been carried out in south-western part of Saudi Arabia. The present paper, therefore, focuses on this region.

\section{METHODOLOGY}

This study has two parts; the first part is studying the effect of air temperature on the worker performance; the second part is studying the effect of noise.

\subsection{SITE SELECTION}

This study has been done in the city of Abha, the capital of Asir Province, approximately 200 kilometers from the northern border of Yemen. It generally has a moderate climate with daily temperatures ranging from 5 to $32{ }^{\circ} \mathrm{C}$; and an annual rainfall of 450 millimeters.

\subsubsection{THE EXPERIMENT (TEMPERATURE EFFECT)}

Subjective experiments were carried out to evaluate the effect of air temperature on human comfort and productivity. Two climate chambers used for the experiments were kept adjacent to each other as shown in Figure (1). Subjects can move between the chambers without passing any other room. Thirty-three Saudi male adults (aged 21-24) participated in the experiment.

The temperatures used are listed in Table 1. Other environmental parameters such as relative humidity, illumination and noise level were kept constant for all temperature conditions stated above as shown in Table 1.

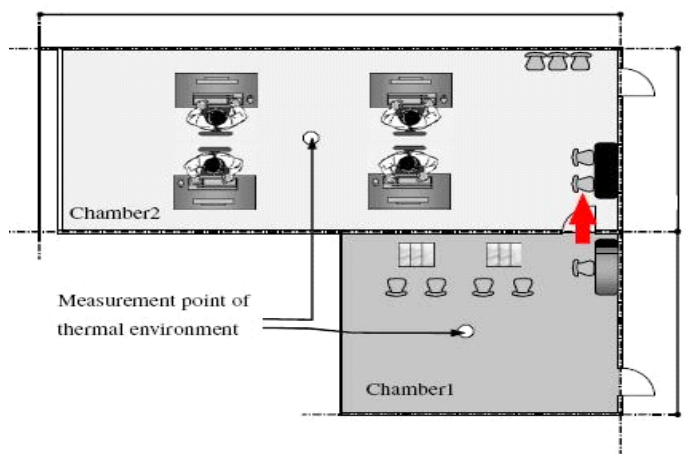

Figure 1: Environment Chambers

TABLE 1: ENVIRONMENTAL FACTORS: TEMPERATURE (4 CASES)

\begin{tabular}{|c|c|c|c|c|c|}
\hline $\begin{array}{l}\text { Measure } \\
\text { d Values }\end{array}$ & Chamber & $\begin{array}{c}\text { Air } \\
\text { Tempe } \\
\text { rature } \\
\left({ }^{\circ} \mathrm{C}\right)\end{array}$ & $\begin{array}{c}\text { Relative } \\
\text { Humidit } \\
y \\
(\% \mathrm{RH})\end{array}$ & $\begin{array}{c}\text { Average } \\
\text { Noise } \\
\text { Level } \\
\text { (dBA) }\end{array}$ & $\begin{array}{c}\text { Illumina } \\
\text { tion } \\
\text { Level } \\
(\mathrm{lx})\end{array}$ \\
\hline & $\begin{array}{c}\text { Chamber } \\
1 \\
\end{array}$ & $21^{\circ} \mathrm{C}$ & $28 \%$ & $45 \mathrm{dBA}$ & $439 \mathrm{~lx}$ \\
\hline Case 1 & \multirow{4}{*}{$\begin{array}{c}\text { Chamber } \\
2\end{array}$} & $18^{\circ} \mathrm{C}$ & $28 \%$ & $45 \mathrm{dBA}$ & $439 \mathrm{~lx}$ \\
\hline Case 2 & & $22^{\circ} \mathrm{C}$ & $34 \%$ & $45 \mathrm{dBA}$ & $439 \mathrm{~lx}$ \\
\hline Case 3 & & $28^{\circ} \mathrm{C}$ & $30 \%$ & $45 \mathrm{dBA}$ & $439 \mathrm{~lx}$ \\
\hline Case 4 & & $31^{\circ} \mathrm{C}$ & $32 \%$ & $45 \mathrm{dBA}$ & $439 \mathrm{~lx}$ \\
\hline
\end{tabular}

After a 15-min exposure to the environment in Chamber 1, the participants were asked to walk into Chamber 2 where they had to assemble three boards under the given environmental conditions. The time needed to complete the assembly process was recorded and averaged over the three groups for the thirty-three assembled boards as shown in Table 2. Assembly times of subjects were compared under different environment conditions to determine the effect of different air temperatures upon performance subjects.

TABLE 2: AVERAGE DATA SUMMARY

\begin{tabular}{|c|c|c|c|c|c|}
\hline \multirow{3}{*}{$\begin{array}{c}\text { Air } \\
\text { Temperature } \\
\left(\mathrm{C}^{\circ}\right)\end{array}$} & \multicolumn{5}{|c|}{ Average Assembly Time ( min) } \\
\cline { 2 - 6 } & $\mathrm{Gp1}$ & $\mathrm{Gp} 2$ & $\mathrm{Gp} 3$ & $\sum \mathbf{y}_{\text {i. }}$ & $\begin{array}{c}\text { Averag } \\
\mathrm{e}\end{array}$ \\
\cline { 2 - 6 } & $1-11$ & $12-22$ & $23-33$ & 40.78 & 13.59 \\
\hline 18 & 13.98 & 13.01 & 13.79 & 41.52 & 13.84 \\
\hline 22 & 13.62 & 12.99 & 14.91 & 41.52 & 17.583 \\
\hline 28 & 18.56 & 18.09 & 16.1 & 52.75 & 18.576 \\
\hline 31 & 20.43 & 18.3 & 17 & 55.73 & \\
\hline
\end{tabular}

\subsubsection{RESULTS}

Statistical analysis was performed on the data to test the Null Hypothesis that "there is no 
significant difference between times needed to complete the task (performance) for the thirty-three subjects under different air temperatures". SPSS for analysis and one-way ANOVA test were used to test the hypothesis. The data indicates that there is no statistical significant difference between the subjects $(\mathrm{P}$-value between subjects $=0.799)$ The $\mathrm{P}$ value shows that there is no preference of one group over the other.

Environmental cases (TEMP) for each group were correlated with the time needed to complete the test $(\mathrm{T})$. The correlation shows that TEMP are strongly correlated to $\mathrm{T}$ $\left(\mathrm{R}^{2}=0.963\right)$ as given in Figure 2. Equation (1) below illustrates the relationship

$\mathrm{T}(\min )=0.0206(\mathrm{TEMP})^{2} 0.589(\mathrm{TEMP})+17$.

Where:

$\mathrm{T}$ : The time needed for assembly (measured in $\min$ )

TEMP: The temperature under constant conditions $\left(\mathrm{C}^{\circ}\right)$.

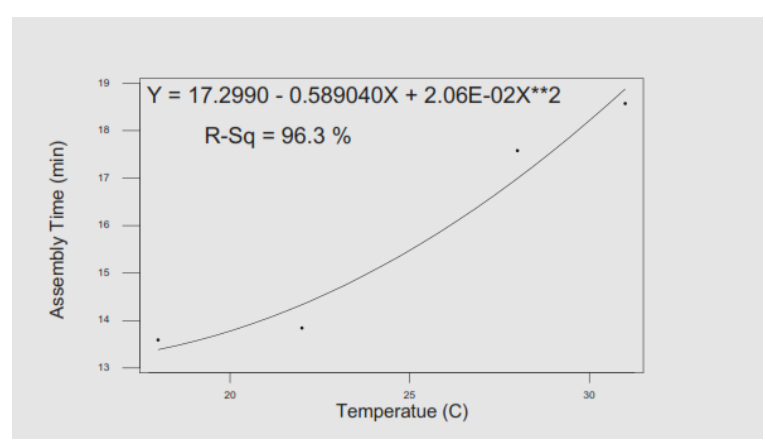

Figure2: Temperature versus Time correlation

\subsubsection{THE EXPERIMENT (NOISE EFFECT)}

The experiment was repeated with the same three Saudi male adult groups. The environmental factors which were used are listed in Table 3, for example the conditions of $18^{\circ} \mathrm{C} / 28 \% \mathrm{RH}$ were set in Chamber 1 . In Chamber 2, three noise levels of $45 \mathrm{dBA}, 65$ $\mathrm{dBA}$, and $80 \mathrm{dBA}$ were examined. Other environmental elements such as relative humidity, illumination and temperature were adjusted to keep constant for all noise conditions.

TABle 3: ENVIRONMENTAL FACTORS- NoISE (3 CASES)

\begin{tabular}{|l|l|l|l|l|l|}
\hline $\begin{array}{c}\text { Measured } \\
\text { Values }\end{array}$ & Chamber & $\begin{array}{c}\text { Air } \\
\text { Temperature } \\
(\mathrm{oC})\end{array}$ & $\begin{array}{c}\text { Relative } \\
\text { Humidity } \\
(\% \mathrm{RH})\end{array}$ & $\begin{array}{c}\text { Average } \\
\text { Noise } \\
\text { Level } \\
(\mathrm{dBA})\end{array}$ & $\begin{array}{c}\text { Illumination } \\
\text { Level ( Ix) }\end{array}$ \\
\hline \multirow{2}{*}{ Case 1 } & \multirow{2}{*}{ Chamber 1 } & $18 \mathrm{oC}$ & $28 \%$ & $45 \mathrm{dBA}$ & $\operatorname{lx} 439$ \\
\hline \multirow{2}{*}{ Case 2 } & \multirow{2}{*}{ Chamber 2 } & $18 \mathrm{oC}$ & $34 \%$ & $65 \mathrm{dBA}$ & $\operatorname{lx} 439$ \\
\cline { 3 - 6 } & & $18 \mathrm{oC}$ & $34 \%$ & $45 \mathrm{dBA}$ & $\operatorname{lx} 439$ \\
\cline { 3 - 6 } Case 3 & & $30 \mathrm{dBA}$ & $1 \times 439$ \\
\hline
\end{tabular}

After a 15-min exposure to the environment in Chamber 1, the participants were asked to walk into Chamber 2 where they had to assemble boards under the given environmental conditions. The time needed to complete the assembly process by the three groups was recorded and averaged over the thirty-three assembled boards as shown in Table 4. Assembly times of subjects were compared under different environment conditions to determine the effect of different noise levels upon performance of subjects.

TABLE 4: AVERAGE DATA SUMMARY

\begin{tabular}{|l|l|l|l|l|l|}
\hline \multirow{2}{*}{ Noise Level dBA } & \multicolumn{5}{|c|}{$\begin{array}{c}\text { Assembly Time Average ( min) } \\
\text { Subject Group }\end{array}$} \\
\cline { 2 - 6 } & $1-11$ & $12-22$ & $23-33$ & $\sum y_{\mathrm{i} .}$ & average \\
\hline $45 \mathrm{dBA}$ & 13.62 & 12.99 & 14.91 & 41.52 & 13.84 \\
\hline $65 \mathrm{dBA}$ & 14.52 & 14.81 & 15.5 & 44.83 & 14.94 \\
\hline $80 \mathrm{dBA}$ & 16.59 & 16.84 & 16.17 & 49.6 & 16.53 \\
\hline
\end{tabular}

\subsubsection{RESULTS}

SPSS and one-way ANOVA was performed on the data in order to test the Null Hypothesis that "there is no significant difference between times needed to complete the task (performance) for the three groups of subjects under different noise levels". The data indicates that there is no statistical 
significant difference between the groups of subjects ( $\mathrm{P}$-value between groups $=.9423$ ), so there is no preference of one group over the other.

Environmental cases $(\mathrm{N})$ for each group were correlated with the time needed to complete the test $(\mathrm{T})$. The correlation shows that $\mathrm{N}$ is strongly correlated to $\mathrm{T}\left(\mathrm{R}^{2}=0.965\right)$ as shown in Figure 3. Equation (2) below illustrates the relationship

$\mathrm{T}(\min )=0.0757(\mathrm{~N})+10.31$

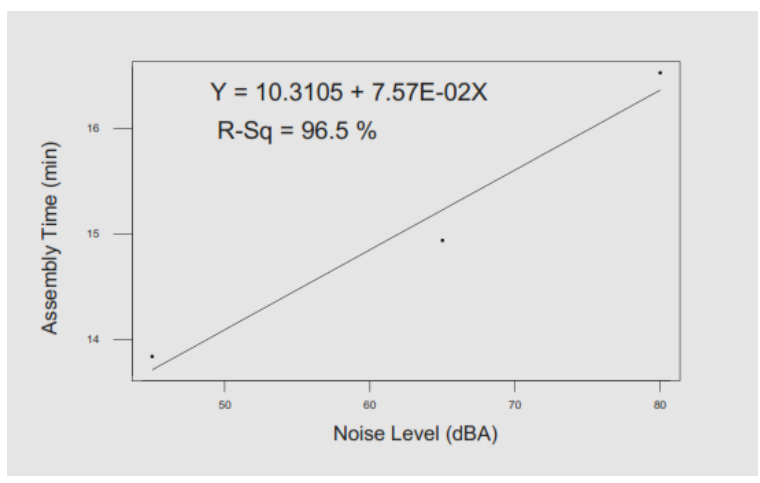

Figure 3: Noise versus Time correlation

\section{CONCLUSION}

Figure 2 shows a curvilinear relationship between indoor temperature and time taken to complete the task by the three groups of 11 participants each. Correlation is high and the coefficient of determination ( $\mathrm{R}$ squared) is also high. That is $96 \%$ of the relationship can be explained by the fact that thermal discomfort caused by high or low air temperature had negative influence on indoor workers' performance in Saudi Arabia. The best temperature for indoor Saudi worker was $18^{\circ} \mathrm{C}$.

Similarly, correlation and coefficient of determination are also high for the straight line curve obtained for noise level versus time taken for the task. Here again, high noise level also had negative influence on indoor Saudi worker's performance. Suitable noise level is below $45 \mathrm{dBA}$ for indoor workers.

\section{REFERENCES}

[1] Lang, Susan S. "Warm offices linked to higher productivity." Human Ecology, Vol. 32, Mar. 2005.

[2] Vischer, Jacqueline, Space Meets Status: designing workplace performance, (New York: Routledge, 2005), 84. 2005.

[3] Vischer, Jacqueline C. "The concept of workplace performance and its value to managers." California Management Review, Vol. 49, 2007.

[4] Polyvios C. "Industrial noise and its effect on human hearing”. J Appl Acoust; 63:35-42, 2002.

[5] Roelofsen P. "The impact of office environments on employee performance: the design of the workplace as a strategy for productivity enhancement". Journal of Facilities Management; 1(3):247-64, 2002.

[6] Wells, Meredith M, Luke Thelen and Jennifer Ruark, "Workspace Personalization and Organizational Culture: Does your workspace reflect you or your company?" Environment and Behavior 39, no. 5: 616-634, 2007.

[7] Sparks, Kate, Brian Faragher, and Cary L. Cooper, "Well-being and occupational health in the 21st century workplace," Journal of Occuaptional and Organizational Psychology, 74, no. 4, Nov 2001.

[8] Niemela R, Hannula M, Rautio S, Reijula K, Railio J. "The effect of indoor air temperature on labor productivity in call centers - a case study". Energy and Buildings, 34:759-64, 2002.

[9] Pepler R.D. and Warner R. "Temperature and learning: an experimental study", paper no 2089. In: Transactions of ASHRAE Annual Meeting; pp. 211-9, 1968.

[10] Onur C, Sinasi Y, Ahmet O. "Hearing parameters in noise exposed industrial workers". J Auris Nasus Larynx; 25:369-75, 1998.

[11] https://globaledge.msu.edu/countries/saudiarabia/economy-accessed on May 13, 2013. 


\section{دراسة محكاة لتأثير العوامل البيئية على اداء العمال فى الغرف المغلقة}

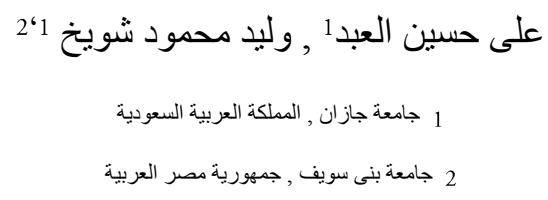

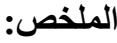

الههف من هذه الدراسة هو استكثاف كفاءة العمل عند التغيرات في درجة الحرارة والضوضاء داخل الغرف المغلقة ـ و أجريت التجربة في الجزء الجنوبي الغربي من المملكة العربية السعودية. واستخدت ثلاثة وثلاثون من الثباب السعودي كعينة. تعرضت ثلاث مجموعات من 11 مشاركا في كل مجموعة للظروف البيئية وهى مكونة من أربع درجات حر ارة مختلفة وثلاثة مستويات الضوضاء، ووقت الانتهاء من المهمة المسجلة للتجميع ـ ووجد أن درجة الحرارة المنلى ومستوى الضوضاء للار اسة هي 18 درجة مئوية و 45 ديسييل على التو الي. وتثير النتائج إلى أن أداء الثخص داخل الغرف في المملكة العربية السعودية يتأثر بتغير درجة الحرارة ومسنوى الضجيج. 